\title{
Applied Elasto-plasticity of Solids
}


Other Macmillan titles of related interest

Advanced Solid Mechanics: Theory, worked examples and problems

P. R. Lancaster and D. Mitchell

Essential Solid Mechanics: Theory, worked examples and problems

B. M. Young

Strength of Materials, third edition in SI units

G. H. Ryder 


\title{
Applied Elasto-plasticity of Solids
}

\author{
T. Z. Blazynski
}

Department of Mechanical Engineering

University of Leeds

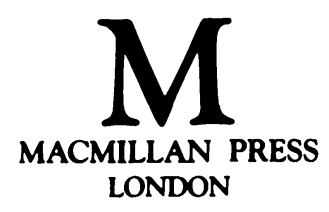


(C) T. Z. Blazynski 1983

All rights reserved. No part of this publication may be reproduced or transmitted, in any form or by any means, without permission.

First published 1983 by

THE MACMILLAN PRESS LTD

London and Basingstoke

Companies and representatives throughout the world

ISBN 978-0-333-34545-0

ISBN 978-1-349-17263-4 (eBook)

DOI 10.1007/978-1-349-17263-4 


\section{Contents}

$\begin{array}{lc}\text { Preface } & \mathrm{xi}\end{array}$

$\begin{array}{ll}\text { Principal Notation } & \text { xiii }\end{array}$

Conversion to S.I. Units $\quad$ Xv

1. Introduction 1

1.1 General considerations 1

1.2 Concepts of design 2

1.3 Materials and design 3

2. Material Properties 4

2.1 Introduction 4

2.2 Determination of stress-strain curves in static conditions 5

$\begin{array}{ll}\text { 2.2.1 Empirical constitutive relations } & 5\end{array}$

2.2.2 Characteristics of the tensile test 6

$\begin{array}{ll}2.2 .3 \text { Compressive testing } & 11\end{array}$

2.2.3.1 Uniaxial compression $\quad 11$

2.2.3.2 Plane strain compression $\quad 12$

$\begin{array}{ll}2.2 .4 \text { Torsion test } & 13\end{array}$

$\begin{array}{ll}2.3 \text { Strain-hardening } & 14\end{array}$

$\begin{array}{ll}2.3 .1 \text { Cause and effect } & 14\end{array}$

$\begin{array}{ll}2.3 .2 \text { Strain rate } & 15\end{array}$

$\begin{array}{ll}\text { 2.3.3 Evaluation of strain rate } & 17\end{array}$

2.4 Properties at high rates of straining 19

$\begin{array}{ll}2.4 .1 \text { Introduction } & 19\end{array}$

$\begin{array}{ll}2.4 .2 \text { Constitutive equations } & 19\end{array}$

$\begin{array}{ll}2.4 .3 \text { Methods of testing } & 20\end{array}$

2.4.3.1 Intermediate strain rates 21

2.4.3.2 Impact strain rates $\quad 21$

2.4.3.3 Higher rates of straining 21

$\begin{array}{ll}2.4 .4 \text { Material properties } & 22\end{array}$ 


\section{CONTENTS}

2.5 Hardness test 23

$\begin{array}{lll}2.6 \text { Friction } & 26\end{array}$

2.6.1 Introduction 26

2.6.2 Mechanism of friction 26

2.6.3 Experimental determination of the coefficient of friction 27

2.7 Plastic flow 28

$\begin{array}{ll}2.7 .1 \text { General observations } & 28\end{array}$

$\begin{array}{ll}2.7 .2 \text { Isotropy and anisotropy } & 28\end{array}$

$\begin{array}{ll}\text { Further reading } & 29\end{array}$

3. Force, Stress and Deformation 30

$\begin{array}{ll}3.1 \text { Introduction } & 30\end{array}$

$\begin{array}{ll}3.2 \text { Stress } & 31\end{array}$

$\begin{array}{ll}\text { 3.2.1 Definition of stress } & 31\end{array}$

3.2.2 Types of stress and their significance $\quad 32$

$\begin{array}{ll}3.2 .3 \text { Cubic equation of stress } & 35\end{array}$

3.2.4 The maximum shearing stress $\quad 39$

$\begin{array}{ll}3.2 .5 \text { Plane stress } & 39\end{array}$

$\begin{array}{ll}3.2 .6 \text { Criteria of yielding } & 41\end{array}$

$\begin{array}{ll}3.2 .7 \text { Residual stress } & 47\end{array}$

$\begin{array}{ll}3.3 \text { Deformation } & 47\end{array}$

3.3.1 General comments $\quad 47$

3.3.2 Strain as a measure of deformation $\quad 48$

3.3.3 Homogeneity and inhomogeneity of deformation $\quad 57$

3.3.4 Experimental determination of deformation and distortion $\quad 58$

$\begin{array}{ll}3.4 \text { Stress-strain relationships } & 64\end{array}$

3.4.1 Stress and strain in the elastic and plastic regimes 64

3.4.2 The applicability of the Prandtl-Reuss rule of flow 67

3.4.3 The methods of accounting for the effects of hardening 68

3.5 Analytical assessment of plastic stress distribution 71

$\begin{array}{ll}3.5 .1 \text { Introduction } & 71\end{array}$

$\begin{array}{ll}3.5 .2 \text { The equilibrium method } & 72\end{array}$

$\begin{array}{ll}\text { 3.5.3 The slip-line analysis } & 74\end{array}$

$\begin{array}{ll}3.5 .4 \text { Upper bound technique } & 75\end{array}$

$\begin{array}{ll}3.5 .5 \text { Visioplasticity } & 76\end{array}$

$\begin{array}{ll}\text { Further reading } & 78\end{array}$

$\begin{array}{ll}\text { Problems } & 78\end{array}$

4. Introduction to Elasto-plastic Relations 81

$\begin{array}{lll}4.1 & \text { Elasto-plastic design concepts } & 81\end{array}$

4.1.1 Systems with and without elastic-plastic interfaces $\quad 81$

$\begin{array}{ll}\text { 4.1.2 Some specific aspects of design } & 82\end{array}$

$\begin{array}{ll}4.2 \text { The concept of plastic instability } & 85\end{array}$ 


\section{CONTENTS}

4.2.1 Instability in tension

$\begin{array}{ll}\text { 4.2.1.1 Uniaxial tension } & 85\end{array}$

$\begin{array}{ll}4.2 .1 .2 \text { General case } & 86\end{array}$

4.2.1.3 Biaxial tension $\quad 88$

$\begin{array}{ll}4.2 .2 \text { Instability in compression } & 90\end{array}$

4.2.2.1 Simple compression $\quad 90$

$\begin{array}{ll}\text { 4.2.2.2 Buckling } & 90\end{array}$

4.2.3 Instability in torsion of thin-walled tubing 90

$\begin{array}{ll}4.3 \text { Elasto-plastic flow in plane strain } & 91\end{array}$

$\begin{array}{ll}\text { Further reading } & 94\end{array}$

$\begin{array}{ll}\text { Problems } & 94\end{array}$

5. Elasto-plastic Bending 96

$\begin{array}{ll}5.1 \text { Introduction } & 96\end{array}$

5.2 Limit analysis and shakedown theorems 96

5.3 Stress systems in statically loaded beams 99

5.3.1 Approximate theory of elasto-plastic bending 99

$\begin{array}{lr}\text { 5.3.1.1 Rectangular sections } & 99\end{array}$

5.3.1.2 Asymmetrical sections $\quad 102$

5.3.2 Determination of bending moments 102

$\begin{array}{ll}\text { 5.3.2.1 General relations } & 102\end{array}$

$\begin{array}{ll}\text { 5.3.2.2 Shape factor } & 104\end{array}$

5.3.2.3 Curvature, deflection and plastic hinge $\quad 104$

$\begin{array}{ll}\text { 5.3.3 Residual stresses } & 111\end{array}$

5.3.3.1 Elastic-perfectly plastic material $\quad 111$

5.3.3.2 The effect of springback 113

5.3.3.3 Elastic-linear strain-hardening material $\quad 114$

$\begin{array}{ll}5.4 \text { Dynamically loaded cantilever } & 117\end{array}$

$\begin{array}{ll}5.4 .1 \text { Introduction } & 117\end{array}$

$\begin{array}{ll}\text { 5.4.2 Plastic hinge } & 117\end{array}$

$\begin{array}{ll}\text { 5.4.3 An assessment of deflection } & 119\end{array}$

$\begin{array}{ll}5.5 \text { Springback effect in statically loaded plates } & 120\end{array}$

$\begin{array}{ll}\text { 5.5.1 Biaxial bending } & 120\end{array}$

5.5.2 Elastic-perfectly plastic material - thin circular plate $\quad 121$

$\begin{array}{ll}\text { 5.5.2.1 Residual curvature } & 121\end{array}$

$\begin{array}{ll}\text { 5.5.2.2 Strains } & 122\end{array}$

5.5.3 Elastic-linear strain-hardening material - rectangular plate $\quad 123$

$\begin{array}{ll}5.6 \text { Buckling of columns } & 126\end{array}$

$\begin{array}{ll}\text { 5.6.1 Introduction } & 126\end{array}$

$\begin{array}{ll}\text { 5.6.2 Elastic-linear strain-hardening columns } & 127\end{array}$

$\begin{array}{lr}5.7 \text { Shakedown of portal frames } & 129\end{array}$

$\begin{array}{lr}\text { Further reading } & 131\end{array}$

$\begin{array}{lr}\text { Problems } & 132\end{array}$ 


\section{CONTENTS}

\section{Torsion of Cylindrical Components}

$\begin{array}{ll}6.1 \text { Introduction } & 134\end{array}$

$\begin{array}{ll}6.2 \text { Elastic analysis } & 135\end{array}$

$\begin{array}{ll}\text { 6.2.1 General consideration of prismatic sections } & 135\end{array}$

6.2.1.1 The stress approach - Poisson's equation 135

6.2.1.2 The displacement approach - Laplace's equation $\quad 140$

$\begin{array}{ll}\text { 6.2.2 Specific geometries } & 140\end{array}$

6.2.2.1 Solid and hollow elliptical sections $\quad 141$

6.2.2.2 Triangular section 144

6.2.3 Treatment of complex shapes and thin-walled cylinders $\quad 147$

$\begin{array}{lll}6.3 \text { Elasto-plastic analysis } & 149\end{array}$

6.3.1 General comments $\quad 149$

$\begin{array}{ll}\text { 6.3.2 Circular prisms } & 150\end{array}$

$\begin{array}{ll}\text { 6.3.2.1 Solid cylinder } & 150\end{array}$

6.3.2.2 Hollow cylinder $\quad 153$

$\begin{array}{ll}\text { 6.3.3 Non-circular prisms } & 157\end{array}$

$\begin{array}{ll}\text { 6.3.3.1 Oval-elliptical section } & 157\end{array}$

$\begin{array}{ll}\text { 6.3.3.2 Equilateral triangle } & 159\end{array}$

$\begin{array}{ll}\text { Further reading } & 160\end{array}$

$\begin{array}{ll}\text { Problems } & 161\end{array}$

7. Axisymmetrical Pressure Systems 163

$\begin{array}{ll}7.1 \text { Introduction } & 163\end{array}$

$\begin{array}{ll}7.2 \text { Thick-walled long tubular cylinders } & 164\end{array}$

7.2.1 The effect of pressure in the elastic regime 164

$\begin{array}{ll}7.2 .1 .1 \text { Single cylinder } & 167\end{array}$

$\begin{array}{ll}\text { 7.2.1.2 Compound cylinders } & 170\end{array}$

$\begin{array}{ll}\text { 7.2.1.3 Hub and shaft assemblies } & 174\end{array}$

7.2.2 The effect of pressure in the elasto-plastic regime 176

$\begin{array}{ll}\text { 7.2.2.1 Primary yielding } & 176\end{array}$

$\begin{array}{ll}\text { 7.2.2.2 Elasto-plastic stress distribution } & 177\end{array}$

$\begin{array}{ll}7.2 .2 .3 \text { Secondary yielding } & 180\end{array}$

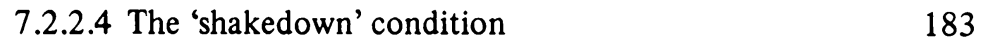

$\begin{array}{ll}\text { 7.2.3 The influence of the cross-bores } & 184\end{array}$

$\begin{array}{ll}\text { 7.2.3.1 General comments } & 184\end{array}$

$\begin{array}{ll}\text { 7.2.3.2 Elastic stress distribution } & 185\end{array}$

$\begin{array}{ll}\text { 7.2.4 Residual stresses in dynamic loading } & 187\end{array}$

$\begin{array}{ll}7.2 .4 .1 \text { Introduction } & 187\end{array}$

7.2.4.2 Implosive welding of duplex cylinders $\quad 187$

7.2.4.3 Explosive autofrettage of forging dies 194

$\begin{array}{ll}7.2 .5 \text { The effect of temperature } & 196\end{array}$

$\begin{array}{ll}\text { 7.2.5.1 Introduction } & 196\end{array}$ 


\section{CONTENTS}

7.2.5.2 Steady-state temperature gradient 196

$\begin{array}{ll}\text { 7.2.5.3 Specific cases } & 198\end{array}$

7.2.5.4 Creep at constant temperature 202

7.3 Thick-walled, hollow spherical containers 203

7.3.1 The effect of pressure in the elastic regime 203

7.3.2 Primary yielding and elasto-plastic relationships 205

7.3.3 Secondary yielding and the shakedown condition 206

$\begin{array}{ll}\text { 7.3.4 Thermal effects } & 207\end{array}$

7.3.4.1 Steady-state temperature gradient 207

7.3.4.2 Combined thermal and pressure effects 209

$\begin{array}{ll}7.4 \text { Thin-walled shells of revolution } & 209\end{array}$

$\begin{array}{ll}\text { 7.4.1 Introduction } & 209\end{array}$

7.4.2 Cylindrical, spherical, toroidal and conical containers 211

7.4.3 The onset of plastic flow 216

$\begin{array}{ll}\text { 7.4.4 Tensile instability } & 217\end{array}$

$\begin{array}{ll}\text { 7.4.4.1 Introduction } & 217\end{array}$

7.4.4.2 Instability in cylindrical and spherical containers $\quad 218$

Further reading $\quad 223$

$\begin{array}{ll}\text { Problems } & 224\end{array}$

8. Rotating Systems 227

8.1 Introduction 227

8.2 Inertial effects in discs - elastic response 227

8.2.1 General conditions 227

8.2.2 Disc of uniform thickness 230

8.2.2.1 Disc with central hole $\quad 230$

8.2.2.2 Solid disc 233

8.2.3 Uniformly stressed disc 234

8.3 Non-rotational effects - elastic response 235

8.3.1 External forces 235

8.3.2 The effect of temperature 236

8.3.2.1 Annular disc of uniform thickness 237

8.3.2.2 Solid disc of uniform thickness 238

8.3.2.3 Disc of variable thickness 239

8.4 Inertial effects in discs - elasto-plastic response 239

8.4.1 Primary yielding 239

8.4.2 Stress distribution in an annular disc 239

8.4.3 Stress distribution in a solid disc $\quad 242$

8.5 Rotating cylinders 244

8.5.1 Thick-walled cylinders 244

8.5.2 Thin-walled cylinders and rings 245 


\section{CONTENTS}

$\begin{array}{ll}\text { 8.6 Stresses in rotating rod systems } & 245\end{array}$

8.6.1 Rotating non-symmetric rod-disc assemblies 245

$\begin{array}{ll}\text { 8.6.2 Thin, uniform rod } & 247\end{array}$

$\begin{array}{ll}\text { Problems } & 248\end{array}$

$\begin{array}{lr}\text { Answers to Problems } & 250\end{array}$

$\begin{array}{lr}\text { Index } & 253\end{array}$ 


\section{Preface}

Exploitation of the possibilities offered by elasto-plastic design - allowing the manipulation of an in-built system of residual stresses - has reached sufficient practical importance to be taught, where appropriate, in the final undergraduate year of various mechanical, civil and production engineering courses and to be included in some M.Sc. syllabuses.

Although the respective areas of elasticity, in particular, and plasticity are adequately covered by a selection of monographs and texts updated in recent years, the area of elasto-plasticity - concerned with the relationship and interaction between elastic and plastic deformations of the same order of magnitude - appears to be somewhat neglected. This book is intended to bridge that gap by explaining how the two regimes of material behaviour are linked in theory and by applying the concepts and principles so established to a variety of basic engineering components to which purely analytical methods of calculation can be applied.

The book is divided into two parts. Chapters 1 to 3 serve as a 'refresher course' on the fundamentals of material behaviour with an analytical description of it and the remaining chapters are concerned with the application of this knowledge to the problems of bending, torsion and axisymmetrical pressure and rotational systems.

To bring the contents completely up to date, discussions of operational, dynamic, industrial techniques are included, although it is recognised that in some undergraduate courses these may not be regarded as necessary. Even so, it is felt that as optional reading, they provide a useful insight into the methods of analytical treatment that are currently available.

Relevant chapters, mostly of the application type, contain a number of carefully selected, solved examples to illustrate the appropriate methods of solution and also a number of unsolved problems, with answers provided, to give the reader an opportunity to practise the expertise acquired.

The mathematical treatment of the subject is entirely within the scope of undergraduate teaching and does not require the knowledge of techniques more advanced than this level suggests. Since the S.I. system is now more generally accepted, numerical examples are given accordingly but a short FPS conversion table is provided for the reader less familiar with its use. Lists of further reading 
that either widen the information provided or furnish more detailed treatment of some of the topics are appended to the relevant chapters.

Many of the examples used are taken from past examination and tutorial papers and in this respect I gratefully acknowledge the contributions made to chapters 6,7 and 8 by Professor B. N. Cole and my other colleagues. Considerable use has been made of the published work of Professor W. Johnson whose permission to include it in the text is much appreciated.

Finally, my thanks go to my wife for her patience during the long period of writing and also for her help with the preparation of the manuscript.

T. Z. BLAZYNSKI

Leeds, 1983 


\section{Principal Notation}

$\begin{array}{ll}a & \text { internal radius } \\ A & \text { cross-sectional area, a constant } \\ b & \text { breadth, outer radius } \\ C & \text { a constant } \\ d & \text { diameter } \\ D & \text { diameter, a constant } \\ e & \text { engineering strain } \\ E & \text { pure strain tensor, Young's modulus } \\ f & \text { volume fraction } \\ F & \text { force } \\ G & \text { modulus of rigidity } \\ h & \text { height, thickness } \\ H & \text { enthalpy } \\ I & \text { stress invariant } \\ J & \text { strain invariant, polar moment of area } \\ k & \text { yield stress in shear, Boltzmann's constant } \\ K & \text { bulk modulus, ratio } b / a \\ l & \text { direction cosine } \\ L & \text { length } \\ m & \text { direction cosine } \\ M & \text { moment } \\ n & \text { direction cosine, power index, number of cycles } \\ N & \text { normal component of force } \\ p & \text { pressure } \\ P & \text { force } \\ q & \text { load per unit length } \\ r & \text { radial distance } \\ R & \text { radius of curvature } \\ S & \text { stress component } \\ S & \text { stress tensor } \\ t & \text { time } \\ T & \text { temperature, torque } \\ u & \text { displacement } \\ & \end{array}$




$\begin{array}{ll}U & \text { energy } \\ \nu & \text { velocity, displacement } \\ V & \text { volume } \\ w & \text { displacement } \\ W & \text { work done, force } \\ W^{\mathrm{e}} & \text { elastic work } \\ W^{\mathrm{p}} & \text { plastic work } \\ Y & \text { yield stress in simple tension } \\ \alpha & \text { linear coefficient of thermal expansion } \\ \gamma & \text { shear strain } \\ \epsilon & \text { natural, logarithmic strain } \\ \epsilon^{\mathrm{e}} & \text { elastic strain } \\ \epsilon^{\mathrm{p}} & \text { plastic strain } \\ \bar{\epsilon} & \text { generalised strain } \\ \dot{\epsilon} & \text { strain rate } \\ \mu & \text { coefficient of friction } \\ \nu & \text { Poisson's ratio } \\ \rho & \text { density } \\ \sigma & \text { stress } \\ \bar{\sigma} & \text { generalised stress } \\ \tau & \text { shear stress } \\ \end{array}$

\section{Subscripts}

$\begin{array}{ll}\mathrm{c} & \text { interface } \\ \mathrm{E} & \text { elastic } \\ \mathrm{H} & \text { homogeneous } \\ \mathrm{I} & \text { redundant } \\ \mathrm{i} & \text { tensorial notation, inner } \\ \mathrm{j} & \text { tensorial notation } \\ \mathrm{L} & \text { loading phase } \\ \mathrm{m} & \text { mean } \\ \mathrm{N} & \text { normal } \\ \mathrm{o} & \text { initial, nominal, outer } \\ \mathrm{P} & \text { plastic } \\ r, \theta, z & \text { co-ordinates } \\ \mathrm{R} & \text { residual } \\ \mathrm{S} & \text { shear } \\ \mathrm{T} & \text { total } \\ \mathrm{U} & \text { unloading phase } \\ \mathrm{V} & \text { volumetric } \\ x, y, z & \text { co-ordinates } \\ \mathrm{Y}_{1} & \text { at first yield } \\ \mathrm{Y}_{2} & \text { at second yield } \\ 1,2,3 & \text { principal directions }\end{array}$




\section{Conversion to S.I. Units}

Length

1 in. $\quad=25.4 \mathrm{~mm}=0.0254 \mathrm{~m}$

$1 \mathrm{ft} \quad=0.3048 \mathrm{~m}$

Area

1 in. $^{2}=6.4516 \times 10^{-4} \mathrm{~m}^{2}$

$1 \mathrm{ft}^{2} \quad=0.0929 \mathrm{~m}^{2}$

Volume
1 in. $^{3}$
$=16.387 \times 10^{-6} \mathrm{~m}^{3}$
$1 \mathrm{ft}^{3}$
$=0.0283 \mathrm{~m}^{3}$

Mass

$1 \mathrm{lb}$

$=0.4536 \mathrm{kG}$

Density

$1 \mathrm{lb} / \mathrm{in}^{3}=27679.9 \mathrm{kG} / \mathrm{m}^{3}$

Moment of inertia

$1 \mathrm{lb} \mathrm{\textrm {ft } ^ { 2 }} \quad=0.04214 \mathrm{kG} \mathrm{m}^{2}$

Force

$1 \mathrm{lbf} \quad=4.4482 \mathrm{~N}$

Moment

$1 \mathrm{lbf} \mathrm{ft} \quad=1.3558 \mathrm{Nm}$ 
CONVERSION TO S.I. UNITS

Stress or pressure

$\begin{array}{ll}1 \mathrm{lbf} / \text { in. }^{2} & =6894.76 \mathrm{~Pa} \\ 1 \text { tonf }^{2} \text { in. }^{2} & =15.4443 \mathrm{MPa}\end{array}$

Energy

$1 \mathrm{ft} \mathrm{lbf} \quad=1.3558 \mathrm{~J}$ 